\title{
Life Writing and Biographical Plays: Emily Carr
}

\begin{abstract}
Emily Carr (1871-1945) as a writer drew on her life experiences for her works: Klee Wyck (1941), The Book of Small (1942), and The House of All Sorts (1944) are like Modernist collages in verbal form, guiding the reader through reflections of widely differing lengths about personal experiences, birds, and meeting people. The posthumously published autobiography Growing Pains (1946) and journals Hundreds and Thousands (1966) add to her palette of "life writing." Whichever genre she was writing in, it is most evident that Art was Carr's greatest priority, implying also several moments of self-doubt, questioning the value or quality of her paintings or writings. Her artistic achievement integrates her ideas about nature, Native people, Art, the dichotomy of "Primitivism" and "Modernism," as well as a striving for simplicity in expression. Carr's extraordinary character invited several artists to make her a mythic figure of Canadian culture.
\end{abstract}

\section{Key words}

Modernism; life-writing; Native art; biographical plays; Emily Carr; Herman Voaden; Jovette Marchessault

Artist, Poet, Singer, tell me what is your goal? By listening, learning, expressing, to find the soul.

(2 December [1932], Hundreds and Thousands)

\section{Carr's Life Writing}

There is a general consensus among critics about the heavily autobiographical nature of Carr's stories - Shadbolt, who approached Carr's oeuvre both from the 
point of view of an art historian and as the editor of Carr's complete writings, claims also that "on a deep psychological level, Carr's painting is autobiographical" (Shadbolt 1997: 6) - at the same time, these are stories in their own right, blending facts (e.g. details of her travels to native villages, and to London and Paris) and fantasy. There are, however, vast differences in the writing practices in her various literary works: while Growing Pains, though subtitled An Autobiography, does not supply the reader with the dates of the different episodes, her journal entries do-Hundreds and Thousands is divided into fourteen sections on a chronological basis, but her entries vary as far as regularity is concerned, e.g. almost half a year passed between the two entries dated January 27 and June 7 [1931] (Carr 1997b: 677-8). Her letters usually specify the exact day of writing. She can also serve as an example for Estelle C. Jelinek's statement that

in contrast to the self-confident, one-dimensional self-image that men usually project, women often depict a multidimensional, fragmented self-image colored by a sense of inadequacy and alienation, of being outsiders or "other." ... Paradoxically, they project self-confidence and a positive sense of accomplishment in having overcome many obstacles to their success $[\ldots]$ [The style] is integral with such a paradoxical self-image: episodic and anecdotal, nonchronological and disjunctive. (qtd. in Walker 1996: 160)

As Shadbolt sees it, in Carr's writings and paintings alike, there is a "particular expressive quality," with Shadbolt adding that "simplicity, conscious crafting is clearly manifest in the deliberate un-stylish style of her work" (1997: 6). Her stories are "sketches, vignettes or anecdotes" (1997: 6) - we could also compare her books to Modernist collages in verbal form, guiding the reader through reflections of widely differing lengths about personal experiences, birds, and meeting people: be they indigenous men and women, disseminators of various religious views, or artists like herself. Putting Carr's The Book of Small (1942) in the tradition of the romance in Canada, Marta Dvorak points out that it is "a retrospective mixture of anecdote, sketch, portrait, autobiography, and essay exemplifying the loose episodic structure of the romance, which projects its voice back over half a century to a geopolitical and temporal space of mutation" (Dvorak 2008: 177).

The style is always very personal and emotionally filled - as Thom says, "the artist's autobiographical texts are [...] subjective" (2006: 256): but, can we expect objectivity from largely autobiographical texts written by an exceptionally sensitive artist? What gives a particular flavour to her literary works is that Carr is "both author and subject of her own books" (Shadbolt 1997: 6); or, to use Craven's phrasing, "[t]he subject matter for all her fiction was her life. She was always the heroine of the stories, even when the story was not ostensibly about her or when it was not written in the first person" (1980: 57). Nothof - borrowing Leigh Gilmore's terminology - contends that Carr's stories constitute "biomythographies," where the self " "auto,' is renamed 'myth"” (Nothof 2006: 145). In Hundreds and Thousands "she writes not only about herself, but also out of her- 
self. [...] she is totally in nature and nature is totally in her. [...] the conspicuous ego of her other writing is replaced by the soul. Here alone does she reveal her spiritual life" (Shadbolt 1997: 12). These features qualify Carr to be a remarkable author of life writing, "a kind of personal or self writing" (Kadar 2002: 660) traditionally very popular in Canada: a short introduction of this particular genre is appropriate here, since it casts light on the type of writing readers of Carr texts are faced with.

This "written form of self-presentation and self-revelation [...] encompasses certain kinds of autobiographical writing" in which the writers "want to be the interpreters of their own experience; the less that is mediated, the less distance there is between the subject and his or her words" (Kadar 2002: 661). ${ }^{1}$

Life writing as a genre [...] revolves around the representation of a life, adopting such forms as the letter, the diary or journal, the memoir, and the autobiography and, sometimes, the biography. [...] it is non-fictional, and it bespeaks a self, whether through a daily record or from the point of view of long memory, whether the audience is limited and private or large and public. This form of life writing is likely to be published, but [...] It may exist in archives [...]

In its second application, "life writing" [...] reveals aspects of a life, of a developing self $[\ldots]$ is a creative opportunity for the writer $[\ldots]$

It is $[\ldots]$ a primary genre, containing many subgenres. Life writing is $[\ldots]$ a literary genre of autobiographical writing that privileges the "I" of the narrative and unmistakably declares its presence to the reader. [...] Life writing narratives $[\ldots]$ exhibit rhetorical and discursive conventions, and are also valuable sources of historical, social, and ethnographical information [...] Critics read life writing as literature.

$[\ldots]$ life writers are declarative authorities of their own experience $[\ldots]$

Memoir and Autobiography [...] reflect on his or her past life and growth, from the point of view of present (and changed) circumstance - so aptly indicated in the title of Emily Carr's 1946 autobiography, Growing Pains [...]

Like autobiographies [...] memoirs describe events in retrospect, and are usually written with eventual publication in mind. Memoirs, however, are often constructed more loosely than autobiographies [...]

Diaries and Letters. The most personal or private of the life writing genres is $[\ldots]$ the diary or the journal. [...] written by the author, more or less daily, for the author's own use [...] a valuable literary genre, with a unique, if narrow and limited point of view. (Kadar 2002: 660-664)

Whichever genre she was writing in, it is most evident that Art - Carr always used a capital "A" - was her greatest priority, implying also several moments of self-doubt, questioning the value or quality of her paintings or writings. Her artistic achievement integrates her ideas about nature, Native people, Art, the dichotomy of "Primitivism" and "Modernism," the striving for simplicity in ex- 
pression - be it in paintings "carrying" a story or stories with a simple plasticity and spatially evocative power. She often reflects upon writing itself ${ }^{2}-$ the urge to write, the process of writing, the struggles, the fear of failure - in her books: her primary motivation was to "word" those things which during my painting life have touched me deeply" (Carr 1997a: 460). Obviously, she saw the two paths of artistic expression as parts of an integrated life-work - "trying to find equivalents for things in words helps me find equivalents in painting" (Carr 1997b: 669). While she was attending courses of creative writing in the summer and fall of 1935, she was re-writing her previous versions of stories:

After a real struggle I finished the story of the crow. Is there anything in the stories? I feel them deeply as I write. I wonder if Flora is right that my painting is waiting on my writing. How interesting it is to work on the two! They are alike and different. I want to write and write longer spells than I want to paint. Writing is more human than painting.

(7 November 1935, Carr 1997b: 766)

I am rewriting "D'Sonoqua's Cats," living it bit by bit - the big wooden image, the woods, the deserted villages, the wet, the sea and smells and growth, the lonesomeness and mystery, and the spirit of D'Sonoqua over it all and what she did to me.

(7 November 1935, Carr 1997b: 767)

Have been struggling with "D'Sonoqua." Big, strong simplicity is needed for these carvings and forests. [...] How does one bridge "feels" with "words"? If only I were better educated [...] It takes a genius to write without education.

(10 December 1935, Carr 1997b: 770)

Her strategy was to achieve a simplicity of form, language and images $^{3}$; as she herself revealed, "I did not know book rules. I made two for myself. They were about the same as the principles I used in painting - Get to the point as directly as you can; never use a big word if a little one will do" (Carr 1997a: 460-01). In her short stories, she does not concentrate on plot: when the International Correspondence Criticism Service returned her Indian story as "not marketable, no plot, only a bit of narrative," Carr reflected upon this remark in her journal, writing that "[ $t]$ he truth of it is I don't want to write that popular mechanical twaddle that is called for. [...] [W] hat joy is there in blowing oneself up with high flavoured impossibilities of plots lacking reality when one longs to just express simply the everyday lovely realities" (Carr 1997b: 778). Therefore, Carr's prose is an impressionistic one, not only in the stories, but very frequently in her journals as well, that offers beautifully phrased descriptions of nature, landscape, seasons, birds, etc.

Carr's literary output can be grouped around four prose genres: short stories (Klee Wyck, The Book of Small, The House of All Sorts, Pause: A Sketch Book, 
The Heart of a Peacock), autobiography (Growing Pains), journals (Hundreds and Thousands: The Journals of An Artist and Opposite Contraries: The Unknown Journals of Emily Carr and Other Writings), and letters (Dear Nan), ${ }^{4}$ totalling up to over 1,500 pages. Carr, therefore, can be considered a prolific artist both as painter and as writer.

Thematically, there are overlappings with regard to autobiographical or journal writings and short stories - occasionally the reader is faced with self-contradictions as well. The key to these features may partly be the temporal aspect: several years had passed between putting down these texts - in her short stories and autobiography she was describing events of her childhood, travellings, and earlier years through the filter of a time-gap of several decades, therefore they cannot be looked at as objective documents of these events (nor did she mean them to be), but she found it important to be honest in both writing and painting: after "sweat and thought and heartaches" she was satisfied with her "Cow Yard" story: "It's honest and every incident is true. [...] I was trying to show life" (2 March [1934], Carr 1997b: 725, 726). Self-contradiction may imply changes of mood as well: evaluating her series of exhibitions lasting for a week in her studio in 1935, on Saturday, April 6, she wrote that "Today's show was horrible and has left me tired out and exceedingly depressed." The next day her balance was just the opposite: "The sixth day of the exhibition is over, the whole thing done with. It has been far beyond expectations in success. I imagine some two hundred people came, and on the whole were keenly appreciative and interested in the work, as was evidenced in many of them coming two and three times" (Carr 1997b: 782-83).

The tone of her texts sometimes verges on sentimentalism and self-pity - she even admits to the former: "I have written hard all day reconstructing my story 'The Heart of a Peacock.' It was the first of my animal stories and very weak and sentimental. I changed the angle somewhat. I think it sounds better now. I got so excited!" (Carr 1997b: 699). In Klee Wyck several stories romanticize the Indians, showing their world as idyllic, treating the female characters - be they real, like Sophie, or mythical, like the totem D'Sonoqua - as "embodying the strength of the native culture" (Craven 1980: 59). Her writing strategy tends to transgress borders in the sense that she frequently incorporates texts by other people into her own: more than once she quotes not only remarks by other people (mainly concerning her work - be these remarks negative or positive), but also letters and even reviews thus manifesting an affinity toward intertextuality (e.g. 1 May [1934], Carr 1997b: 786; 11 December [1934], Carr 1997b: 805-06). This element is all the more important since in this fashion Carr creates documents with regard to artists (particularly Lawren Harris) who did not keep letters or journals, and whose correspondence has not yet been published. On one occasion in Hundreds and Thousands the generic variety is enriched by a short scene reconstructing the dialogues with her sisters, casting an ironic light on their characters (27 March [1936], Carr 1997b: 819-21).

Although Carr started to write late in her career, as Shadbolt says, "[t]he rewriting and final drafting of the works, often begun many years before, $[\ldots]$ was 
done between 1934 and 1941," she did have earlier "scrabs"5 to draw on: "[d] uring the discouraged years of the 1920s when she was painting little, she wrote [...] her "stories"' (qtd. in Carr 1997: 3), but she had burned her diaries written as a young person, after discovering that her oldest sister had not only read them, but had also mocked Emily because of them: "I used to write diaries when I was young but if I put anything down that was under the skin I was in terror that someone would read it and ridicule me, so I always burnt them up before long. [...] I could not write my innermost thoughts if anybody was to read them" (23 November [1930], 1997b: 668). Carr created a different type of diary, too: as Lamoureux points out, she made

autobiographical caricatures [...] forty-seven watercolours from 1910 recounting episodes from the pan-Canadian voyage that preceded her Quebec City - Liverpool crossing en route to Paris. [...] the artist reveals in them a concern to construct her own image, much like in a diary. [...] In her caricatures Carr appears as a tourist, a nomad, an explorer, and a woman in exile, sketching a heroic but self-mocking version of the difficult situations she had to overcome. (Lamoureux 2006: 51)

Carr after all was one of those early Modernists who travelled from the periphery to the centres, living a "nomadic" life in "exile" for several years. Decades later she would work on the verbal form of her experiences and preoccupations in her years of training.

She attended courses on writing in 1926-27 and in 1934 (Walker 1990: xxiv, Carr 1997b: 754-80), but it was not until her ailing periods in old age that she turned towards writing seriously: she said of the stories that later made up the Klee Wyck volume that their "quiet strength healed my heart" (Carr 1997a: 461). Her doctors recommended it since resuming painting would have been far too exhausting for her. Before submitting her stories for publication, however, she did need the advice and help of an expert: Ira Dilworth volunteered for this task happily.

Carr was not an intellectual par excellence: her upbringing was very much in the Puritan traditions, her childhood readings were practically limited to the Bible - she recounts in The Book of Small, that "Father did not believe in fairy stories for children" (Carr 1997c: 97) - but she became an ardent reader later in life, particularly when her various illnesses prevented her from doing the more strenuous work of painting. She did have a small collection of artbooks "with titles such as How to See Modern Art, The New Art, Painters of the Modern Mind, and Western Art and the New Era. Many of the passages in these books were underlined and annotated by her" (DeSoto 2008: 134), but in many cases she relied on other people's recommendations to get and read books. Eric Brown suggested that she get a copy of Fred Housser's A Canadian Art Movement (1926); Lawren Harris gave her a list of Theosophy literature, but also recommended Catherine Dreier's Western Art and the New Era before she made up her mind to go to New 
York (Carr 1997a: 446). Housser, on the other hand, "had introduced Carr to the poetry of Walt Whitman and perhaps also to the writing of Emerson (a copy of whose essay 'Nature' was among her books). Whitman's Leaves of Grass and other volumes of his poetry were daily reading and travel companions to the end of her life; they are referred to and quoted often in the Journals" (Shadbolt 1990: 79); sometimes she even copied stanzas by Whitman, like those from "A Song of the Rolling Earth" on November $3^{\text {rd }}, 1932$ (Carr 1997b: 675). Very often, her reactions to books were quite heated: she mentions throwing a book on Theosophy at the wall, ${ }^{6}$ on another occasion, her prudishness overcomes her rebellious modernist self when saying of D. H. Lawrence's St. Mawr that it is

so sexy. Everything these days is people talking of sex and psychology. I hate both. This would-be-smart psychology makes me sick; it's so impertinent, digging round inside people $[\ldots]$ and making hideous false statements, and yanking up all the sex problems, the dirty side of everything. They claim they are being real and natural, going back to the primitive. Animals are simple and decent with their sex. Things happen naturally and just are. It's all simple and straight, but we - ugh! - we've fouled it all [...] dirty books, filthy cinemas, muck everywhere.

(26 November 1930, qtd. in Carr 1997b: 669)

Her intensive correspondence - particularly with fellow British Columbian artist Nan Cheney, starting in 1930 and lasting till the end of her life - reveals that Carr liked to read artists' life-stories, Katherine Mansfield's short stories, and was choosy in her literary taste. She also liked going to concerts:

A happy day. Harry Adaskin of the Hart House Quartet came to lunch and we talked more than we ate. The Quartet was playing modern music tonight [...] it stirred deep. Lovely music - rebellion, ferocity, tenderness, resignation - superbly played. Our hostess did not like it [...] Are people afraid to dip down and find out about life, I wonder. The man who wrote it and the men who interpret it have to dig and drink dregs to produce it. (18 November [1934], Carr 1997b: 768)

Geza de Krész took my hand and held it tight [...] It is splendidly wonderful, the things that lie beyond, that we try to capture with instruments or paint or words [...] They found my latest work youthful and inspiring in spirit. It refreshed them. I work on at these canvases and long for more depth and intensity.

(26 November [1934], 1997b: 768)

The beloved Hart House quartette pay an annual visit which is a joy, both the music and the men themselves.

(Letter to Nan Cheney, 25 October [1935], qtd. in Walker 1990: 31) 
Many artists and writers went to see her when on a visit to Victoria: "The Hart House Quartette, were in Vic. last week no matter how rushed they are they always find time for a good long visit with me - nice men. What's-his-name Scott? calls upon me tomorrow" ("Confederation" poet Duncan Campbell Scott is this visitor) (Letter to Nan Cheney, postmarked 13 Mar 1941, qtd. in Walker 1996: 306). Carr's studio from the mid-1930s on, then, functioned also as a "centre in the periphery" for artists visiting from Canada, the United States, and occasionally even from Europe: "I had a visitor from Germany yesterday. She says the tendency in German art today is to give minute surface detail. She had seen, she said, no work just like mine" (17 January [1935], Carr 1997b: 776).

A few years earlier, in 1931, a concert by the Seattle Symphony made her reflect about her relationship with her sisters and about painting:

First time in years we have been out together. It was delightful as we sat there unanimously enjoying it. I couldn't help wondering why it was that we could all meet and be lifted up in the music while had it been a picture exhibit we'd have had no shared sympathy at all. Has music something art lacks? The new art does lift one but so few understand. [...] They want the surface representation; the soul behind it they do not want and cannot feel. Surely we artists must fail somewhere. Why can't we lift the veil and reveal the soul if the musician can? Is the eye more earthy than the ear?

(entry for 4 February [1931], Carr 1997b: 672)

Good music that gives one the best feelings always leads me away from man, away from cities out and off to spaces (or woods). Why?

(entry for the same day, qtd. in Carr 2003: 34-35)

As her various types of writing reveal, Carr liked to go to concerts and lectures; in London she often went to the theatre, but - interestingly - she never mentioned having been to the cinema, nor did she write about films. It turns out that she preferred live musical performance to recordings, and also that she regularly listened to the radio, so she was not against new communication media.

Recognition came relatively late to Carr - not as late, though, as she herself often suggested. Her first exhibitions were not well received: she particularly regretted the complete indifference toward her paintings in France and in the French style (1912, 1913), after all, it was in France that "Emily Carr became a modernist [...] (and) she was determined to apply what she had learned in France to the landscape and indigenous culture of the West Coast" (Laurence 1996: 14). A crisis of almost a decade and a half followed when she hardly painted at all (although she made pottery and rugs with Indian motifs). While critics generally underline the lack of creativity on the part of Carr between 1913 and 1927, Charles Taylor thinks that "it may well have been that she found her new strength and inner vitality, not despite the barren years, but because of them" (1977: 177) - and indeed, Carr's own evaluation of a similar situation, namely the "wasted years" in London, sup- 
port Taylor's argumentation: "I had learned more during those frustrated years in England than I had supposed" (Carr 1997a: 424). The experiences accumulated during these years formed the "raw material" for The House of All Sorts, and her painting activities after the milestone exhibition at the National Gallery in Ottawa (1927), along with meeting and befriending the members of the Group of Seven was a breathtaking artistic-intellectual experience for the hitherto completely isolated Carr, resulting in pictures of great profundity, and followed by gradual recognition in major Canadian cities, as well as in Chicago, London and Amsterdam. Expanding recognition and the wider dissemination of her art work increased her feeling of responsibility as painter: "I feel more 'writey' than 'paintry' these days, \& it make[s] me feel 'bliterish.' now that it's my recognized job, I feel, I should be painting not wasting my time. trying to scribble at my age. but writing does not require so much physical energy [...] typed for 2 hours" (Letter to Nan Cheney, 27 March 1938, qtd. in Walker 1990: 69).

\section{Plays about Carr}

Emily Carr's writing was related to the tradition of life-writing, as described in the previous passages. The plays about her personality and her art invite considerations about staged real life stories and biographies which offer multiple layers by employing an artist (actor/actress) to impersonate another artist (in our case, a painter and a writer) in live performance for an audience that is physically present, therefore the boundaries of real and art become very hard to draw - "we expect to be told the truth about someone's life, we believe that the people we encounter are real, that they live outside the text" (Grace 2006: 16). Investigating the problematics of the theatre as an art form and AutoBiography as a sub-genre of drama, Sherrill Grace (2006: 14) explains the immense popularity of "lifestorying" in Western culture during the past few decades:

AutoBiography - whether as prose memoir, biography, feature film or documentary life story [...] portraiture, photography, "reality TV" programs, online diaries (blogs), performance arts, and auto/biographical plays - appeals to audiences because we live in a culture of $m e$ or $I$ at a time when access to this cultural production is easy. [...] AutoBiographies satisfy our desire for story at the same time as they promise to give us truths (if not Truth), to provide meaning, identity, and possibly even order, in an otherwise incoherent, arbitrary, and often violent world. [...] They are [...] more democratic than many other forms of communication [...] the autobiographical voice and eye/I are available to minorities and to groups, such as women, who have been excluded from the dominant discourse and whose stories have been dismissed as worthless.

Grace concludes that a "prose biography can never do what a live performance does" (2006: 21), because these plays "also invite us to re-think who we are and 
how we come to see ourselves - and others" (16). The innate voyeuristic desire is thus accompanied by a turn to the self, the self of the viewers by triggering their memory to evoke similar situations or by pushing them towards evaluating emotional, moral, or philosophical issues.

Anne Nothof (2006: 137) sums up the main components of plays about artists as follows: "The dramatic portrait of an artist assumes an attempt at accuracy and authenticity, or at least at a recognizable likeness; it typically includes iconic anecdotes and demonstrates a creative genius in formation and in action. Too often portraits of artistic genius succumb to clichés and exploit the eccentricities and 'abnormalities' of the artist." It is a slippery terrain, the sources at the disposal of the author (letters, diaries, journals) may often offer one-sided versions of important events in the artists' lives or of the critical reception of their work - and, at the same time, it is very rewarding, since people are eager to know the "secret" of the artist. These plays involve three artists at least: the artist about whom the play is written, the playwright, and the actor/actress - each of whom may have different tools (in Carr's case painting and writing), as well as the playwright and the actress who cannot help but contribute their own artistic search to the shaping of the artist-character on stage. To this list, we may add the contribution of "backstage" artists, first of all, that of the metteur-en-scène, and the set and costume designers all of whom have an important role in evoking the given artist on the stage. By choosing a real person as protagonist, it is not only the life - art border that is hard to differentiate in the play, but also that of the artists' own forms of expression and the representation of their own artistic struggle under the veil of the artist-protagonist of the play proper.

Eva-Marie Kröller in her 1986 article elaborated on the works (poems, novels, music, dance) inspired by the art and personality of Emily Carr concluding that "Emily Carr is a model for other Canadian artists [...] and her existence a touchstone for their own achievement. [...] Literary (and musical) interpretations of Emily Carr are not only an alternative, but a complementary version of her life" (96). Anne Nothof in 1998 looked at the stage versions of the Carr "legend" exhaustively, while in her article of 2006 she analysed two plays about Carr together with a British play about Van Gogh. Here we restrict our focus to how Carr was conceived as a stage character by a contemporary of hers $(\mathrm{H}$. Voaden), written in the 1950s and first performed in 1960, and by a feminist artist (J. Marchessault) in 1990.

Herman Voaden (1903-1991) is generally considered as the most remarkable representative of expressionism in English-Canadian theatre and drama who, as editor of Six Canadian Plays in 1930, pioneered in not only the dissemination of new dramatic work, including the typically "modernist" form of the one-act play, but in the "Introduction" to this anthology also outlined the path along which a newly emerging Canadian drama should proceed in the footsteps of the representatives of the "Irish Renaissance" (Yeats, Synge) and of Whitman as the North American ideal. For Voaden the Group of Seven painters could set the tone for other forms of art as to how to view the "new country" and how to plant these 
new visions into artistic expression: his own plays of the late 1920s and 1930s attempt to move beyond the traditional possibilities of a mainly verbal form of expression and invite musical and visual elements to produce a complex stage image, most often about the experience of the Canadian North. His creative period of "symphonic expressionism" lasted for about a decade and a half, starting in 1928; as Anton Wagner (1985: 188) explains it, "Voaden's own search for meaning had a strongly subjective, autobiographical basis, and developed in a specific Canadian artistic context whose cultural nationalism, philosophical idealism and abstract and symbolist aesthetic were shared by other leading cultural figures." These elements, namely the autobiographical references, the nationalistic convictions, idealism and the interest in abstract and symbolic ways of expression, coincide with Carr's convictions - indeed, both Carr and Voaden were fascinated by the pictures of the Group of Seven and by Housser's aesthetic evaluations, and both were acquainted with Theosophical ideas, although neither of them joined that group. Instead, both Carr and Voaden "developed an essentially religious, communal conception of art as a substitute for conventional Christian dogma" (Wagner 1985: 189); also, they thought of art as a quest. Voaden's statement that "neither the culture nor the art of another people can be finally a substitute for our own" (qtd. in Wagner 1985: 190) expresses what Carr was striving for. Given that there are so many parallel elements in the artistic convictions and general views of Voaden and Carr, where can the reason lie for the overall discrepancy between the chosen subject matter (Emily Carr's life story) and the stage realization by Voaden?

It was two decades after editing the anthology of Canadian plays, and half a decade after Carr's death that Voaden made the first version of his play about Emily Carr, but kept working on it for several years more. The still-unpublished text of Emily Carr: A Stage Biography with Pictures is available online: both in structure and in dramaturgy it is closer to traditional, realist drama than to the experimental expressionist plays of Voaden's interwar period. In the "Acknowledgements" before the play, Voaden underlines that it is "stage biography, not a documentary" (1960, unpublished: 4), although he used Carr's autobiographical writing as his starting point. The plot is divided into three acts and revolves around phases, turning points in Carr's life from her teenage years, through her stay in London to her mature period and finally her death in Victoria. In this play, two of her sisters, Alice and Edith, are among the characters (while Marchessault chose Lizzie to "counterpoint" Emily) and a suitor is present in each act. With a solution reminding us of Brecht's early "Lehrstücke," Voaden offers two options for the first scene of Act II: in the first version, the dialogue is between Emily and Mayo, her visiting boy-friend in London; the second version includes Alice, too, besides Emily and Martyn, Emily's suitor. The basic tension in the play is arranged along two axes: one is Emily's dilemma between pursuing art or getting married and becoming a home-maker, the other is her childhood "epiphany" in the lily-field, presented as a deep secret in the drama. As a traditional symbol, the lily stands for purity, innocence, and virginity in Western culture (in 
medieval paintings, held by Gabriel, it is often the attribute of the "Annunciation" scene), but in Voaden's play this aspect is not wholly evident. Voaden creates an Emily character somewhat different from her own "self-portraits" in her writings; although the Emily of Voaden's play is also rebellious and sometimes hysterical, her conflicts with her oldest sister Edith are softened in the play, sometimes verging on sentimental scenes; the other aspect of the protagonist is also different from what we can read in Growing Pains, or Hundreds and Thousands, namely Voaden's Emily is more "flirty" with her boyfriends than in the source materials.

Voaden envisioned a stage harmony of the verbal, visual and audible, relying strongly on Carr's published work (taking passages from it) to be supported by projections of her paintings and music - as Nothof puts it, he was striving "to produce a kind of Bildungsroman of Wagnerian proportions" (1998: 86). The first staging in 1960, however, could not live up to these high aspirations - instead it turned out to be a sequence of episodes chronicling certain (sometimes pivotal) moments in the artist's life (Nothof 1998: 86). Carr's artistic struggle, attacks on the patriarchal system, and isolation did not turn into a convincing stage figure of the experimenting and fighting female artist - mainly because there lurks a melodramatic undertone in crucial situations, be they her resistance to her oldest sister's arrogance or to the traditional expectations of saying "yes" to a suitor and leading a life of comformism. ${ }^{7}$ Carr's language in her writings is very visual, evocative, sometimes even poetic - Voaden's dialogues are in a different tone and his traditional (occasionally drawing-room) dramaturgy means a rupture from the possibilities Carr's life and her texts offer. This cannot be bridged by staging solutions in the realistic vein: as Nothof (1998: 88) mentions, in Victoria, B.C. in 1966 they even put some of Carr's original furniture on stage as part of the set - a non-realistic (symbolist or expressionist) approach might have offered the audience a more suggestive picture, but Voaden's mainly prosaic dialogues cannot really invite it. This can result mainly from the radical change Voaden's concept of the theatre and drama went through after 1943: the war deprived him of his idealistic outlook, he could no longer believe in the fusion of visionary, poetic and aesthetic elements on the stage with music and stylized dance, and obviously he was not ready for a move in the direction of an existentialist (or even absurd) drama, therefore he reached back to the tradition of drawing-room play in the realistic vein. For this choice, however, neither the personality nor the artistic convictions of Emily Carr seemed to suit.

Jovette Marchessault's (b. 1938) artistic career and life experiences manifest parallel elements with those of Carr: she, too, was active in several artistic media - painting, sculpture, writing, playwriting. Like Carr, Marchessault relied on her own life experiences for her novels, and refused the traditional patriarchal order, finding the Catholic Church to be one of its embodiments. Marchessault devoted much attention to women artists in her stage work: she wrote a play about Violette Leduc, and another about Alice B. Toklas and Gertrude Stein, before turning her attention to Emily Carr, as the outstanding female artist from Canada. While Carr's parents settled down in Victoria not long before her birth, Marchessault 
was of mixed French-Canadian and Amerindian parents, so she had first-hand personal experience with Native people and their lives, to which Emily Carr felt so close.

Le voyage magnifique d'Emily Carr uses the motif of travelling on various levels - travelling was, as we have seen, crucial for Carr's artistic development, be the destinations centres of art life in Europe or in North America, or the native villages and rain forests of her sketching tours. Marchessault herself had her "nomadic" years, making an initiatory voyage across the central and northern part of the American continent, searching for her roots in her thirties. The voyage has traditionally been conceived as life-metaphor, and is present as such in her play, which won the Governor General's Award in 1992, half a century later than Carr did with her Klee Wyck.

Marchessault's play is a flow of poetic images in ten scenes with Emily Carr in her late fifties as protagonist. The other characters are Lizzie, her second older sister (in her sixties), Sophie, her Native friend, who also impersonates the mystical figure of Goddess D'Sonoqua, and Lawren Harris, appearing also as "L'Accordeur d'âmes," a go-between connecting earthly life with the beyond who possesses "une aptitude illimitée à communiquer avec les mortels planétaires" (Marchessault 1990: 43). Most scenes strongly rely on Carr's life writing, but there are inconsistencies as far as the age of the characters is concerned: Harris in the play is in his thirties; in reality the age difference between Carr and Harris was fourteen years. The scenes with Lizzie serve to establish Emily's character as extravagant, as different from everyday people, and to demonstrate her protests against paternal authority; as Nothof observes, Lizzie "articulates a doctrinal social and religious point of view" (1998: 99). Her second voyage back in time takes us to the world of the totems in the forest, based on Carr's story about D'Sonoqua: the painter is here surrounded by a group of cats, evoking the cat as mythological figure in Egypt, Persia and the Himalayas. The stage is dominated by the deep greens of Carr's paintings supporting the transition from life to the world of the souls - here her obsession for expressing movement in her pictures appears together with her self-doubts. Marchessault makes conscious use of typically female elements: the cats, the Moon, the house and cows, the latter two suggesting the image of maternity.

The gender aspect is present all through the play - with a special stress in "Tableau IV" and "Tableau V" when she gets an invitation letter for the National Gallery exhibition addressed as Monsieur Emily Carr, Victoria, confirming the general belief that "serious" art can be produced only by male artists and when later she is faced by a painting of A. Y. Jackson.

The climax of the play arrives in her third voyage back in time, with all the crucial characters present: Carr's dedication to the native cause (evoking the injustice the aboriginals were exposed to) and to art embrace each other by "un travail intérieur" (Marchessault 1990: 65). As the character of Harris puts it: "Vos tableaux sont tellement imprégnés de vie. Vous peignez des images! Des éclats! On dirait que vous soumettez tout votre être à la force des couleurs. Cette façon 
de peindre les vieux totems du monde amérindian: vous les placez sur un piédestal de phosphorescence" (65). The two artists here reach a state of exaltation, defining what is important in art for them and what they refuse. Harris - as in reality - provides ample energy for Emily Carr to face the lack of understanding back in Victoria, where she has a reputation as an aberrant, foolish woman, who calls her "tente-roulotte motorisée" the Elephant (82) and prefers "les huttes enfumées des Indiens plus que nous," as Lizzie observes (91). In the final scene - after Lizzie's death - she occupies her father's armchair, thus gaining authority and soon after that the L'Accordeur produces her "little book," so Emily Carr the writer is presented, as well, who declares that "Tout ce que j'écrirai sera fragmentaire en regard de ceux qui l'ont vécu" (108).

The dramaturgy of Marchessault's play is in the Modernist way: instead of a linear story offering beginning, middle, and end, it is a sequence of images, visions, blending biographical events with dreams, evoking real life and spiritual characters alike, discussing everyday events and supernatural capacities. "Like many expressionist plays, The Magnificent Voyage of Emily Carr is loosely structured as a journey to a 'New World,' in this case one in which feminist values and aesthetics will be recognized and celebrated" (Nothof 1998: 97). The essential questions of birth, life, art, and death are present all through the play, with a special emphasis on the division line, the "seuil de l'Incertain" (Marchessault 1990: 35). The voyage for Emily is the voyage to complete her mission in art - for Lizzie, it is but the road to death. Self-reflection is present on multiple levels: it is a play about a female artist, introducing other artist characters, like fellow painter Lawren Harris, Sophie, the basket maker who can give "des forces surnaturelles" with her hands massaging (while Lizzie's "savaient dénouer les nerfs, apaiser les pires tensions" (55). Art is often the subject of the dialogues and the protagonist achieves mythic dimensions. The poetic power of Marchessault's text facilitates the transitions between the two basic worlds - everyday and spiritual - of the play. As Nothof (1998: 98) records,

For the premiere production in French by Le Théâtre d'Aujourdhui (1990), as Natalie Rewa explains, Augustin Rioux's scenographic design "made fascinating connections between the surface of a picture hanging on a wall and that of the rectangular playing area [...]. Rioux framed the acting area by arranging seating on all four sides, leaving a small aisle around the stage ... This 'performance canvas' was bisected by a totem pole reminiscent of the many images of D'Sonoqua painted by Carr." (37)

Carr's personal struggle for art and recognition, and her extraordinary character invited artists to make her a mythic figure Canadian culture was in great need of for self-confirmation and for showing heroes of their own as part of the process to create cultural identity for the country. 


\section{Notes}

The research for this paper was made possible through Sabbatical grant No. 81102 of the Hungarian Scientific Research Fund.

After having achieved success with her paintings, Eric Brown suggested that someone write a biography of Carr. Carr commented on the issue in a letter to Nan Cheney, postmarked 13 March 1941: "I do not feel eligible for a biography. In first place I'm not DEAD \& I don't think these things should be wrote till one is. ... I have written one ... Maybe some day I'll get to it maybe not" (Walker 1990: 307). Also, she thought, no male writer could fully understand her motivations and decisions.

Several entries can be cited as good examples of this:

"Here I am, little book, having neglected you for some time. I have written to Lawren twice, so that does you out of your little spiel for I work it off on him instead of on you. It's all the same as long as you can get it off your chest, only it's easier when there is flesh and blood at the other end and, more than that, an answering spirit." (16 January [1934], Carr 1997b: 720).

"Ah, little book, I owe you an apology. I've got to like you despite how silly you seemed to me when Lawren suggested I start you. You help me to sort and formulate thoughts and you amuse me, which is more than housecleaning does" (18 March [1934], Carr 1997b: 728).

"Now little journal - diary - whatever you call yourself, let's see if I can clarify my thoughts a little through you, defacing your white surface to clean up some hazy muddle below the surface. [...] We are so terrifically alone in our big things: birth, death, religion, art. [...] Well, what do you write for? To please folks who aren't interested really, or to something within yourself?" (22 April 1934, Carr 2003: 69). A year later, on April $3^{\text {rd. }}$ "There is something comforting about writing, sort of explaining things to yourself" (Carr 2003: 99).

"Little book, I started to take a summer school course in short story writing so perhaps I can improve in my treatment of you. I'd like to make little daily incidents ring clean cut and clear as a bell, dress 'em up in gowns simple and yet exquisite like Paris gowns" (9 July [1934], Carr 1997b: 754-55).

In Shadbolt's view, "[i]n her writing [...] Carr carries her innocence and simplicity in front of herself like a banner [...] also thereby shading herself from the critical scrutiny of those she was quick to see as intellectually and socially more sophisticated than herself" (qtd. in Carr 1997b: 11).

As Doreen Walker puts it, "Emily Carr made it clear that her hastily written letters were intended solely for the recipient; she surely never imagined that they were material for publication" (Walker 1990: xxxii).

"Painting" with a brush or with words were two sides of the same coin and based on the same strategy by Carr, so what she mentions in Growing Pains with regard to her work as painter may be relevant to her writing, too. "Unknowingly I was storing, storing, and unconscious, my working ideas against the time when I should be ready to use this material" (Part II "Home Again") (Carr 1997a: 346).

"Bess sent me a Madam Blavatsky book which infuriated me I flung it across the room when partly read \& then I burnt it \& told Bess \& Lawren I did not like Theosophy. I liked \& believed in plain bible, \& I burnt Madam B \& they sighed and we've never mentioned the matter since." (Carr's letter to Nan Cheney, postmarked 22 December 1940, qtd. in Walker 1990: 280).

7 Act II, alternative scene 1 (Voaden 1960: 38-39):

Martyn: Good afternoon, Alice.

Alice: Hello, Martyn. 


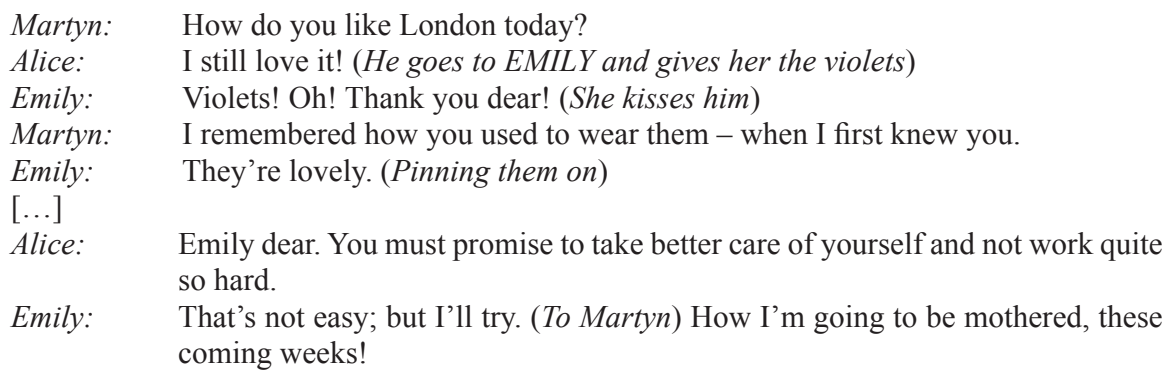

\section{References}

Carr, Emily (1997a) Growing Pains: An Autobiography [1946]. In: The Complete Writings of Emily Carr (1997). Intro. Doris Shadbolt. Vancouver: Douglas \& McIntyre. 293-471.

Carr, Emily (1997b) Hundreds and Thousands: The Journals of an Artist [1966]. In: The Complete Writings of Emily Carr (1997). Intro. Doris Shadbolt. Vancouver: Douglas \& McIntyre. 653-893.

Carr, Emily (1997c) The Book of Small [1942]. In: The Complete Writings of Emily Carr (1997). Intro. Doris Shadbolt. Vancouver: Douglas \& McIntyre. 87-192.

Carr, Emily (2003) Opposite Contraries: The Unknown Journals of Emily Carr and Other Writings. Ed., Intr. Susan Crean. Vancouver: Douglas \& McIntyre.

Craven, Mary Louise (1980) 'Emily Carr'. In: Heath, Jeffrey M. (ed.) Profiles in Canadian Literature 1. Toronto: Dundurn Press. 57-64.

DeSoto, Lewis (2008) Emily Carr (Extraordinary Canadians series). Intr. John Ralston Saul. Toronto: Penguin Canada.

Dvorak, Martha (2008) 'The English-Canadian Novel and the Displacement of the Romance'. In: Nischik, Reingard (ed.) History of Literature in Canada: English-Canadian and French-Canadian. Rochester, NY: Camden House. 174-193.

Grace, Sherrill (2006) 'Theatre and the AutoBiographical Pact: an Introduction'. In: Grace, Sherrill, and Jerry Wasserman (ed.) Theatre and AutoBiography: Writing and Performing Lives in Theory and Practice. Vancouver: Talonbooks. 13-29.

Kadar, Marlene (2002) 'Life Writing'. In: New, William H. (ed.) Encyclopedia of Literature in Canada. Toronto: University of Toronto Press. 660-666.

Kröller, Eva-Marie (1986) 'Literary Versions of Emily Carr'. Canadian Literature, 109, 87-98.

Lamoureux, Johanne (2006) 'The Other French Modernity of Emily Carr'. In: Hill, Charles C., Johanne Lamoureux, and Ian M. Thom (ed.) Emily Carr: New Perspectives on a Canadian Icon. Vancouver: Douglas \& McIntyre. 42-61.

Laurence, Robin (Intr.) (1996) Beloved Land: The World of Emily Carr. Vancouver: Douglas \& McIntyre.

Marchessault, Jovette (1990) Le voyage magnifique d'Emily Carr. Ottawa: Leméac.

New, William H. (2002) Encyclopedia of Literature in Canada. Toronto: University of Toronto Press.

Nothof, Anne (2006) 'Resonant Lives: The Dramatic Self-Portraiture of Vincent and Emily'. In: Grace, Sherrill, and Jerry Wasserman (ed.) Theatre and AutoBiography: Writing and Performing Lives in Theory and Practice. Vancouver: Talonbooks. 137-151.

Nothof, Anne (1998) 'Staging a Woman Painter's Life: Six Versions of Emily Carr'. Mosaic 31(3), 83-109.

Shadbolt, Doris (1990) Emily Carr. Vancouver: Douglas \& McIntyre.

Shadbolt, Doris (1997) 'Introduction'. In: The Complete Writings of Emily Carr (1997). Vancouver: Douglas \& McIntyre. 3-14. 
Taylor, Charles (1977) 'Introduction'. 'Emily Carr’. In: Six Journeys: A Canadian Pattern. Toronto: Anansi. i-vi, 153-187.

Thom, Ian M. (2006) 'Locating Emily Carr: Major Writings on Her Work and Life, 1945 to 1990'. In: Hill, Charles C., Johanne Lamoureux, and Ian M. Thom (ed.) Emily Carr: New Perspectives on a Canadian Icon. Vancouver: Douglas \& McIntyre. 248-257.

Voaden, Herman (1960) Emily Carr: A Stage Biography with Pictures. Unpublished. 4 March 2011. $<$ http://www.lib.unb.ca/Texts/Theatre/voaden/emilycarr.htm>

Wagner, Anton (1985) 'Herman Voaden's “New Religion”'. Theatre History in Canada 6(2), 187201.

Walker, Doreen (ed.) (1990) Dear Nan: Letters of Emily Carr, Nan Cheney and Humphrey Toms. Vancouver: University of British Columbia Press.

Walker, Stephanie Kirkwood (1996) This Woman in Particular: Contexts for the Biographical Image of Emily Carr. Foreword by William Closson James. Waterloo, ON: Wilfrid Laurier University Press.

Katalin Kürtösi is Associate Professor at the Department of Comparative Literature, University of Szeged, Hungary, specializing in twentieth-century Canadian culture with a focus on Modernism, drama, theatre and interculturalism. She authored two monographs and published several papers in Canada, Germany, Italy and the Central European region. She was Editor-in-chief of the Central European Journal of Canadian Studies/Revue d'études canadiennes en Europe centrale from 2001 to 2009 and was awarded the Certificate of Merit by the International Council for Canadian Studies in 2010 .

Address: Dr. Katalin Kürtösi, Department of Comparative Literature, University of Szeged. Egyetem u. 2, H-6722 Szeged, Hungary. [email: kurtosi@hung.u-szeged.hu] 
